\title{
Development of the Gateway ${ }^{\circledR}$ System for Cloning and Expressing Genes in Entamoeba histolytica
}

\author{
Mayuresh M. Abhyankar ${ }^{1}$, Amelia E. Hochreiter ${ }^{1}$, Sarah K. Connell ${ }^{1}$, Carol A. Gilchrist ${ }^{1,{ }^{*},}$ \\ Barbara J. Mann ${ }^{1,2}$, and William A. Petri Jr $\mathbf{r}^{1,2,3}$ \\ 1 Department of Medicine, University of Virginia, Charlottesville, VA, USA \\ 2 Department of Microbiology, University of Virginia, Charlottesville, VA, USA \\ 3 Department of Pathology, University of Virginia, Charlottesville, VA, USA
}

\begin{abstract}
The early branching eukaryote Entamoeba histolytica is a human parasite that is the etiologic agent of amebic dysentery and liver abscess. The sequencing of the $E$. histolytica genome combined with the development of an E. histolytica microarray has resulted in the identification of several distinct gene expression profiles associated with virulence. The function of many modulated transcripts is unknown and their role in pathogenicity unclear. They however represent a pool of potential virulence factors that could be targets for the development of novel therapeutics. Efficient tools and methods to characterize these novel virulence-associated genes and proteins would be beneficial. Here we report the use of the Gateway ${ }^{\circledR}$ cloning system to generate the $E$. histolytica expression vector pAHDEST. To test the usefulness of this system, the vector was used to construct a plasmid containing a recombinant version of the locus EHI_144490, which encoded a protein of unknown function. The recombinant gene was expressed and the recombinant protein, which was Strep-Myctagged, showed a cytoplasmic localization in transfected trophozoites. This expression vector with the Gateway® system should facilitate investigation into the functions of novel proteins in $E$. histolytica.
\end{abstract}

\section{Keywords \\ Entamoeba histolytica; Gateway® Vector; EHI_144490}

Entamoeba histolytica is an enteric aerotolerant parasite that can colonize the large intestine, and invade through the intestinal epithelium to cause amebic colitis and liver abscess [1]. The sequencing of the E. histolytica genome has provided new opportunities to identify virulence factors. Distinct gene expression profiles that may be associated with pathogenicity have been identified by microarray analysis via the comparison of transcripts of cultured HM1: IMSS $E$. histolytica trophozoites to amebae isolated from mouse ceca [2]. These analyses have produced

\footnotetext{
*Address correspondence to Carol A Gilchrist, Dept. of Medicine, Division of Infectious Diseases and International Health, Building MR4, Rm 2126, PO Box 801365, Charlottesville VA22908. Tel: 434924 5167/434 2437243 Fax: 4349240075 e-mail: E-mail: cg2p@virginia.edu.

Addresses of authors who have moved from the institution where the work was performed:-Sarah K. Connell, Virginia Commonwealth University, School of Medicine, 1101 E. Marshall Street, Richmond, VA 23298-0565

Publisher's Disclaimer: This is a PDF file of an unedited manuscript that has been accepted for publication. As a service to our customers we are providing this early version of the manuscript. The manuscript will undergo copyediting, typesetting, and review of the resulting proof before it is published in its final citable form. Please note that during the production process errors may be discovered which could affect the content, and all legal disclaimers that apply to the journal pertain.
} 
fairly large data sets [2-7]. An efficient and high throughput method is needed for cloning and analyzing the function of the proteins encoded by these transcripts.

The Gateway (Invitrogen) system has been used successfully to stably express open reading frames (ORFs) from P. falciparum by recombinational cloning, which like E. histolytica, contains an AT-rich genome [8-10]. The Gateway® system also has the potential to rapidly transfer cloned inserts from one vector to another [11]. To construct the E. histolytica 'Destination' plasmid we used the well-characterized plasmid pGir308 as the backbone of the new construct [12]. This vector uses the E. histolytica ferredoxin promoter, which drives strong expression of cloned genes in vivo and in vitro $[2,13]$. The vector also carries a hygromycin resistance gene, which permits the use of this vector in co-infection studies with other $E$. histolytica shuttle vectors that carry G418-selectable markers [14].

The vector pGir308 was digested with $X b a \mathrm{I}$ to remove the structural gene encoding the $\mathrm{Tet}^{\mathrm{R}}$ protein, and the Klenow fragment of DNA polymerase used to fill-in the sticky ends. The Gateway ${ }^{\circledR}$ attR cassette was then subcloned between the blunt ends as per the manufacturer's instructions (Invitrogen). The Gateway ${ }^{\circledR}$ attR cassette with att sites enabled recombinational cloning [15-17], and also contained a chloramphenicol resistance marker and a $c c d B$ death gene [18]. The resultant vector, pAH-DEST could only be maintained in bacterial strains resistant to the effects of $c c d B$ (Figure 1-A).

To evaluate the high-throughput Gateway ${ }^{\circledR}$ cloning strategy with pAH-DEST as a cloning and E. histolytica expression vector, we selected the open reading frame EHI_144490. This locus was designated EHI_144490 in the new annotation of the E. histolytica genome (http://pathema.tigr.org), but was deposited in Genbank by the earlier E. histolytica genome sequencing project release as XM_650868 [19]. The EHI_144490 transcript was reduced by a factor of 6.25 in trophozoites isolated from mouse ceca 29 days after infection when compared to cultured amebae. (p<0.0001)[2]. Bioinformatics analysis indicated that locus EHI_144490 was part of an E. histolytica gene family (Ehis-1) of conserved hypothetical proteins. Ehis-1 consists of fifteen genes, ten of which were represented by unique gene sets on the Affymetrix array E_his-1a520285. Five family members were expressed at above background levels, and all were significantly down-regulated at day 29 post challenge in the mouse model of amebiasis (XM_650868, XM_646771, XM_645239, XM_649852, XM_647536) [2]. EHI_144490

(XM_650868) was one of the most highly expressed genes in this family. Members of Ehis-1 share a region similar to the sigma factor 54 ATPase domain. This domain has been shown to interact with RNA polymerase in bacteria (EMBL-EBI InterPro \# IPR002078) and is present in a number of bacterial proteins involved in two-component signal transduction [20]. The Ehis-1 family proteins also contain a domain with similarity to the SEPTIN domain (InterPro Family \# IPR000038). The cytoplasmic septin proteins are involved in cell division and binding of GTP in higher eukaryotes and are localized at the cleavage furrow in dividing cells [21, 22]. Thus the function(s) and locations of this family of proteins are unclear.

The coding sequence of EHI_144490 was PCR amplified from HM1:IMSS genomic DNA. The primers used were designed to introduce two N-terminal tags in tandem: Strep (WSHPQFEK) and c-myc (EQKLISEEDL). These tags permit identification and one step purification of the recombinant protein. The PCR product was then cloned into the Gateway ${ }^{\circledR}$ entry vector-pCR8/GW/TOPO (Invitrogen). The att recombination sites in the vector allowed for rapid recombination into a variety of destination vectors. The LR Clonase system (Invitrogen) was then used to transfer the recombinant EHI_144490 cassette from the entry clone into pAH-DEST destination plasmid using the manufacturer's instructions. While aberrant recombination events have been reported to occur only at extremely low frequencies our experience suggests that resequencing the final expression cassette is an essential step in quality control [17]. The pAHDEST-EHI_144490 expression plasmid generated as described 
above was used to transfect HM1: IMSS trophozoites using the standard protocol [23,24]. Approximately $4 \times 10^{6}$ trophozoites carrying pAH DEST-EHI_144490 were then used for protein purification. A Strep-Tactin spin column (IBA) was used to affinity purify the recombinant protein from total cell lysate. As expected the eluted protein showed a $68 \mathrm{kDa}$ band on a western blot when probed with anti c-myc antibody (Fig. 1-B).

To determine the subcellular location of the product of EHI_144490 the transfected amebae were grown at $37^{\circ} \mathrm{C}$ in TYI-S-33 medium containing $50 \mu \mathrm{g} / \mathrm{ml}$ hygromycin. These trophozoites $\left(10^{6}\right)$ were then bound to glass cover slips in a 24 -well plate for $30 \mathrm{~min}$ at $37^{\circ} \mathrm{C}$ in TYI-S-33 medium. Adherent amebae were fixed in $3 \%$ paraformaldehyde for $30 \mathrm{~min}$ at room temperature (RT) followed by permeablization using $0.2 \%$ Triton X-100 in PBS for 1 min. Nonspecific binding was blocked with $20 \%$ goat serum and $5 \%$ bovine serum albumin (Sigma) in PBST for $2 \mathrm{~h}$ at RT. The cover slips were then incubated with anti-cMyc antibody (Santa Cruz) for $2 \mathrm{~h}$ at RT followed by three washes with PBST. Cya-3 conjugated donkey anti-mouse secondary antibody (Santa Cruz) was added for $30 \mathrm{~min}$ at RT followed by DAPI staining. The cover slips were washed three times and mounted using Vectashield (Sigma) mounting medium. Confocal images were visualized using a Zeiss LSM 510 laser scanning microscope (Carl Zeiss). This experiment was repeated with two independent constructs and transfected strains. The recombinant protein was located in the cytoplasm (Fig. 2).

In conclusion, a Gateway®-based vector applicable for high-throughput cloning and expression of recombinant proteins in E. histolytica trophozoites was constructed. The vector was used to epitope tag and show that open reading frame EHI_144490 encoded a protein with a cytoplasmic location. This new expression system should facilitate the study of unique proteins in E. histolytica.

\title{
Acknowledgements
}

This work was supported by NIH grant AI-37941. The Pathema-Entamoeba Database is an NIAID Bioinformatics Resource Center (BRC).

\author{
Abbreviations \\ ORF \\ open reading frame \\ myc \\ myelocytomatosis viral oncogene homolog \\ strep \\ streptavidin \\ $\operatorname{amp}^{\mathbf{R}}$ \\ ampicillin resistance \\ $\mathbf{c m}^{\mathbf{R}}$ \\ chloramphenicol resistance \\ tet $^{R}$ \\ tetracycline resistance \\ fdx \\ ferredoxin \\ hgl \\ heavy subunit of the galactose and $N$-acetylgalactosamine lectin
}




\section{References}

1. Haque R, Mondal D, Duggal P, Kabir M, Roy S, Farr BM, Sack RB, Petri WA Jr. Entamoeba histolytica infection in children and protection from subsequent amebiasis. Infect Immun 2006;74:904-909. [PubMed: 16428733]

2. Gilchrist CA, Houpt E, Trapaidze N, Fei Z, Crasta O, Asgharpour A, Evans C, Martino-Catt S, Baba DJ, Stroup S, Hamano S, Ehrenkaufer G, Okada M, Singh U, Nozaki T, Mann BJ, Petri WA Jr. Impact of intestinal colonization and invasion on the Entamoeba histolytica transcriptome. Mol Biochem Parasitol 2006;147:163-176. [PubMed: 16569449]

3. Ackers JP, Mirelman D. Progress in research on Entamoeba histolytica pathogenesis. Curr Opin Microbiol 2006;9:367-373. [PubMed: 16824782]

4. Davis PH, Schulze J, Stanley SL Jr. Transcriptomic comparison of two Entamoeba histolytica strains with defined virulence phenotypes identifies new virulence factor candidates and key differences in the expression patterns of cysteine proteases, lectin light chains, and calmodulin. Mol Biochem Parasitol 2007;151:118-128. [PubMed: 17141337]

5. MacFarlane RC, Singh U. Identification of differentially expressed genes in virulent and nonvirulent Entamoeba species: potential implications for amebic pathogenesis. Infect Immun 2006;74:340-351. [PubMed: 16368989]

6. Ehrenkaufer GM, Eichinger DJ, Singh U. Trichostatin A effects on gene expression in the protozoan parasite Entamoeba histolytica. BMC Genomics 2007;8:216. [PubMed: 17612405]

7. Ehrenkaufer GM, Haque R, Hackney JA, Eichinger DJ, Singh U. Identification of developmentally regulated genes in Entamoeba histolytica: insights into mechanisms of stage conversion in a protozoan parasite. Cell Microbiol 2007;9:1426-1444. [PubMed: 17250591]

8. Aguiar JC, LaBaer J, Blair PL, Shamailova VY, Koundinya M, Russell JA, Huang F, Mar W, Anthony RM, Witney A, Caruana SR, Brizuela L, Sacci JB Jr, Hoffman SL, Carucci DJ. High-throughput generation of P. falciparum functional molecules by recombinational cloning. Genome Res 2004;14:2076-2082. [PubMed: 15489329]

9. Tonkin CJ, van Dooren GG, Spurck TP, Struck NS, Good RT, Handman E, Cowman AF, McFadden GI. Localization of organellar proteins in Plasmodium falciparum using a novel set of transfection vectors and a new immunofluorescence fixation method. Mol Biochem Parasitol 2004;137:13-21. [PubMed: 15279947]

10. Skinner-Adams TS, Hawthorne PL, Trenholme KR, Gardiner DL. GATEWAY vectors for Plasmodium falciparum transfection. Trends Parasitol 2003;19:17-18. [PubMed: 12488219]

11. Walhout AJ, Temple GF, Brasch MA, Hartley JL, Lorson MA, van den Heuvel S, Vidal M. GATEWAY recombinational cloning: application to the cloning of large numbers of open reading frames or ORFeomes. Methods Enzymol 2000;328:575-592. [PubMed: 11075367]

12. Ramakrishnan G, Vines RR, Mann BJ, Petri WA Jr. A tetracycline-inducible gene expression system in Entamoeba histolytica. Mol Biochem Parasitol 1997;84:93-100. [PubMed: 9041524]

13. Gilchrist CA, Mann BJ, Petri WA Jr. Control of ferredoxin and Gal/GalNAc lectin gene expression in Entamoeba histolytica by a cis-acting DNA sequence. Infect Immun 1998;66:2383-2386. [PubMed: 9573137]

14. Vines RR, Purdy JE, Ragland BD, Samuelson J, Mann BJ, Petri WA Jr. Stable episomal transfection of Entamoeba histolytica. Mol Biochem Parasitol 1995;71:265-267. [PubMed: 7477110]

15. Landy A. Dynamic, structural, and regulatory aspects of lambda site-specific recombination. Annu Rev Biochem 1989;58:913-949. [PubMed: 2528323]

16. Nunes-Duby SE, Matsumoto L, Landy A. Half-att site substrates reveal the homology independence and minimal protein requirements for productive synapsis in lambda excisive recombination. Cell 1989;59:197-206. [PubMed: 2529039]

17. Hartley JL, Temple GF, Brasch MA. DNA cloning using in vitro site-specific recombination. Genome Res 2000;10:1788-1795. [PubMed: 11076863]

18. Bernard P, Gabant P, Bahassi EM, Couturier M. Positive-selection vectors using the F plasmid ccdB killer gene. Gene 1994;148:71-74. [PubMed: 7926841]

19. Loftus B, Anderson I, Davies R, Alsmark UC, Samuelson J, Amedeo P, Roncaglia P, Berriman M, Hirt RP, Mann BJ, Nozaki T, Suh B, Pop M, Duchene M, Ackers J, Tannich E, Leippe M, Hofer M, 
Bruchhaus I, Willhoeft U, Bhattacharya A, Chillingworth T, Churcher C, Hance Z, Harris B, Harris D, Jagels K, Moule S, Mungall K, Ormond D, Squares R, Whitehead S, Quail MA, Rabbinowitsch E, Norbertczak H, Price C, Wang Z, Guillen N, Gilchrist C, Stroup SE, Bhattacharya S, Lohia A, Foster PG, Sicheritz-Ponten T, Weber C, Singh U, Mukherjee C, El-Sayed NM, Petri WA Jr, Clark CG, Embley TM, Barrell B, Fraser CM, Hall N. The genome of the protist parasite Entamoeba histolytica. Nature 2005;433:865-868. [PubMed: 15729342]

20. Morett E, Segovia L. The sigma 54 bacterial enhancer-binding protein family: mechanism of action and phylogenetic relationship of their functional domains. J Bacteriol 1993;175:6067-6074. [PubMed: 8407777]

21. Kinoshita M. The septins. Genome Biol 2003;4:236. [PubMed: 14611653]

22. Haarer BK, Pringle JR. Immunofluorescence localization of the Saccharomyces cerevisiae CDC12 gene product to the vicinity of the 10-nm filaments in the mother-bud neck. Mol Cell Biol 1987;7:3678-3687. [PubMed: 3316985]

23. Olvera A, Olvera F, Vines RR, Recillas-Targa F, Lizardi PM, Dhar S, Bhattacharya S, Petri W Jr, Alagon A. Stable transfection of Entamoeba histolytica trophozoites by lipofection. Arch Med Res 1997;28(Spec No):49-51. [PubMed: 9033009]

24. Asgharpour A, Gilchrist C, Baba D, Hamano S, Houpt E. Resistance to intestinal Entamoeba histolytica infection is conferred by innate immunity and Gr-1+ cells. Infect Immun 2005;73:45224529. [PubMed: 16040963] 
A

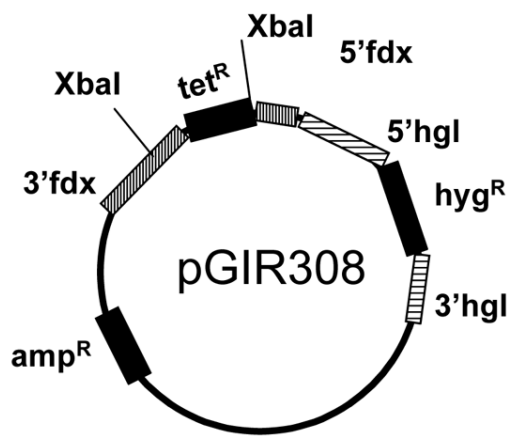

\section{Xbal digestion and fill in}

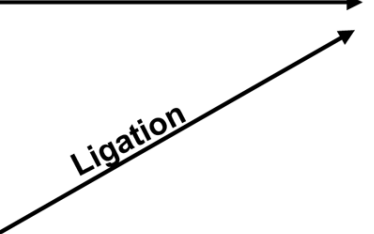

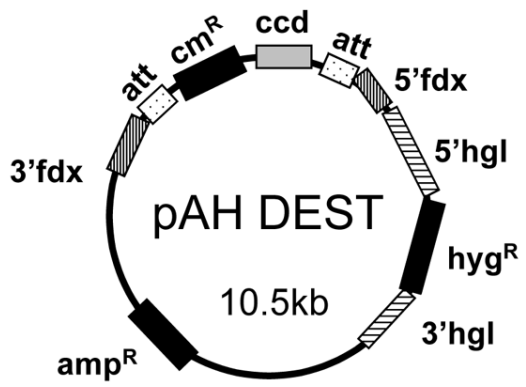

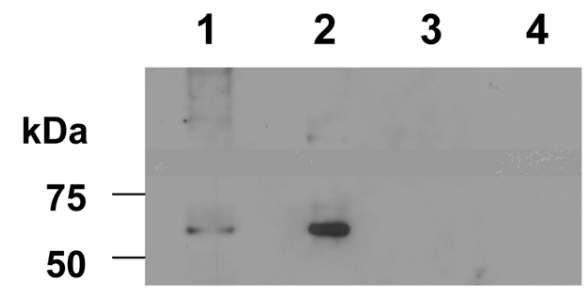

Fig. 1.

(A) Construction of the $E$. histolytica Gateway ${ }^{\circledR}$ expression vector pAH-DEST. The tet ${ }^{\mathrm{R}}$ cassette from pGIR308 was replaced with the Gateway ${ }^{\circledR}$ (Invitrogen cat. \# 11828-029) cassette containing $a t t \mathrm{R}$ recombination sites flanking a $c c d \mathrm{~B}$ gene and a chloramphenicol-resistance $\left(\mathrm{cm}^{\mathrm{R}}\right)$ gene. The new expression vector contained an ampicillin ${ }^{\mathrm{R}}$ gene for bacterial selection. (B) Affinity purification of recombinant EHI_144490. The cell lysate from trophozoites expressing Strep-Myc tagged recombinant protein was affinity-purified using a Strep-Tactin column (IBA, Gmbh) as per the manufacturer's instructions and immunoblotted. The blot was probed with anti-Myc antibody. As expected a predominant $68 \mathrm{kDa}$ band was seen in whole cell lysate (lane 1) as well as in the purified fraction (lane 2). Minor higher molecular mass bands that might represent protein aggregation or post-translational modifications were also identified. No proteins recognized by the anti-Myc antibody were seen in lysate (lane 3 ) or purified fraction (lane 4) controls prepared from trophozoites transfected with pAH DEST vector alone. 


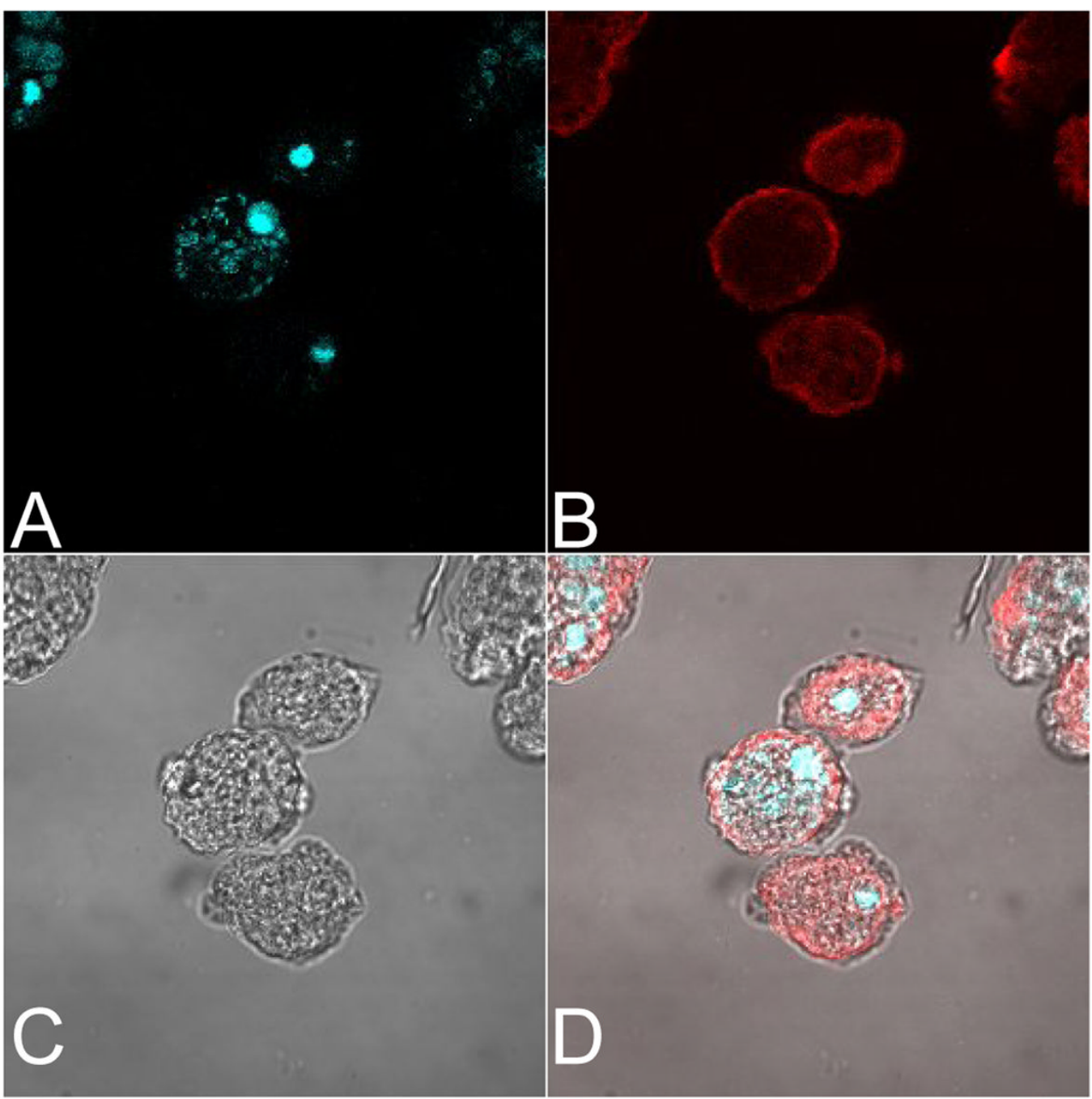

Fig. 2.

Cytoplasmic location of recombinant EHI_144490. HM1: IMSS trophozoites were transfected with the Gateway ${ }^{\circledR}$ construct expressing recombinant EHI_144490. Nuclei were stained with DAPI (blue, panel A). The recombinant protein was detected with monoclonal anti-Myc antibody and Cya 3-conjugated donkey anti-mouse antibody (panel B). The bright field image is shown in panel $\mathrm{C}$, and panel $\mathrm{D}$ shows the merged images. The recombinant protein was cytoplasmic (red, panel B and D). Amebae probed with secondary antibody alone did not show staining (data not shown). The images were obtained using a Zeiss LSM 410 laser scanning confocal microscope. 